\title{
Movie-Review as Media in Learning Interreligious Relations at University of Darussalam Gontor
}

\author{
Y K Yahya ${ }^{1}$, S I Nikmah ${ }^{2}$, N Anjani ${ }^{3}$ \\ University of Darussalam Gontor, Ponorogo, Indonesia ${ }^{1,2,3}$ \\ \{yuangga4@unida.gontor.ac.id ${ }^{1,2}$, apt@,unida.gontor.ac.id ${ }^{3}$ \}
}

\begin{abstract}
Establishing inter-religious harmony needs mutual-understanding between those who have different religions. This article attempts to provide a media in learning interreligious relation in order to make harmony among people with different religions. By using Husserl's phenomenology perspective which requires epoche and eidetic vision, this article is to figure out that digital era also contributed greatly to provide information related to other faiths. Movie-review is selected for millennial generation hobby and does not require a lot of infrastructure. Moview-review is given as a task for course of Interfaith Relations in University of Darussalam Gontor. This task is intended to build a positive opinion and good memory about coexistence and multiculturalism. Most of students participating in the course agreed to look at importance of maintaining good relations between religious communities and postpone stereotyping.
\end{abstract}

Keywords: Interreligious Communication, Movie-review, Digital Era

\section{Introduction}

The contestation of Indonesia presidential elections in 2019 was over, but there are a lot of problems left after this 4th annual event, including polarization among Indonesian people with different religious backgrounds. This polarization is caused by differences in preference for presidential selection which propagate difference views of life, trust, and faith [1]. A state with motto 'Unity in Diversity' is dealing with a potential split between different background of tribes, nations, and religions. The issues of sectarianism can be triggered by communal violence, as happened in the Middle East regions in recent decades [2].

Therefore, spirit of peace and tolerance need to be maintained as best as possible. Preparing the young generation who have mature knowledge, open-minded, and resourceful in addressing the differences is one of the best ways to keep this nation's existence several centuries ahead. This is a reason that Department of Comparative Study of Religions, Faculty of Ushuluddin, University of Darussalam Gontor puts curriculum 'Interreligious Relations' into the formal course. Through these lessons, students are expected to be wise in dealing with their differences and playing an active role in conflict resolution.

In that course, lecturers use movie-review as one method of learning. One of the reasons underlying use of such methods is a growing theory that children of millennial generation are very close in using of technology and audio-visual [3]. This learning method is expected to provide a sense of comfort and interest of learners to attend classes.

Moreover, a moral message behind the film is complex, since the message can be verbal and non-verbal. Verbal message consists of dialogue, narration, and text. Non-verbal message 
may be a behavior, character, expression, appearance, lighting, camera angles, background music, color, and other signs that have a particular meaning in the film [4].

Film is also a popular culture with two functions, i.e. construction of reality and representation of socio-cultural reality. The first function is to expose a wide range of realities in order to leading opinion of audience in accordance with filmmakers' (producer, screenwriter, and director) direction and desire. Therefore, it is often considered as a 'side effect' of the messages conveyed through digital media such as movies, since it only highlights something which 'is considered' important for author [5].

The second function is a representation of social reality. A media of representations to convey the message is through the film. According to Arnold (2008), relationship between film as a medium for representation and reality behind its representation is a two-way relationship. In one side, film or television is a real picture of social, cultural, and political reality, and on the other hand, events in real life is affected by vision and story behind the film [6].

This study intended to illustrate the effectiveness of using movie-review method in teaching the subject 'Interfaith Relations'. By using survey to students, this research attempts to describe effects of film as a medium for learning on students' religious tolerance. It will provide examples of success stories in cultivating virtues and creating a good memory of cross-religious communication.

\section{Method}

This is a qualitative descriptive study. The data is summary of of the questionnaire that was distributed to students at the end of the semester and learning outcomes in the form of the Mid-Semester Exam and Final Semester Exam.

The subjects of this study are the fourth semester students in Departement of Comparative Study of Religions, Faculty of Ushuluddin, University of Darussalam Gontor, Ponorogo. The total of 21 students are Muslim and have an educational background in Islamic boarding schools more than 4 years.

The object of research is film entitled Bhajrangi Bhaijan (2015) in Indian language and Aisyah, Biarkan Kami Bersaudara (2016) in the Indonesian language. The first film told about relations between India and Pakistan, between Hindu and Muslim, which are depicted in a young Hindi who wants to bring back a Pakistani mute girl back to her home after getting lost in India. The second film told about Islamic-Catholic relations in East Nusa Tenggara, which is described in Muslim teacher from Bandung who teaches in elementary school in a small village in the district of East Nusa Tenggara.

The instrument was a questionnaire containing questions about student's agreement or disagreement with the movie-review method in teaching subject 'Interfaith Relations'. Their level of understanding is also measured through final assignment in the form of a brief response to the film and the message that they should capture in the film.

\section{Result and Discussion}

The researchers held survey to the whole students about their interest in watching movie, movie-suitability with the lesson, their understanding about messages in the movie, the values that contained in movie and the suitability of the given assignment. Here is the result of the survey: 
Fig. 1. Student's Interest in Watching Movie

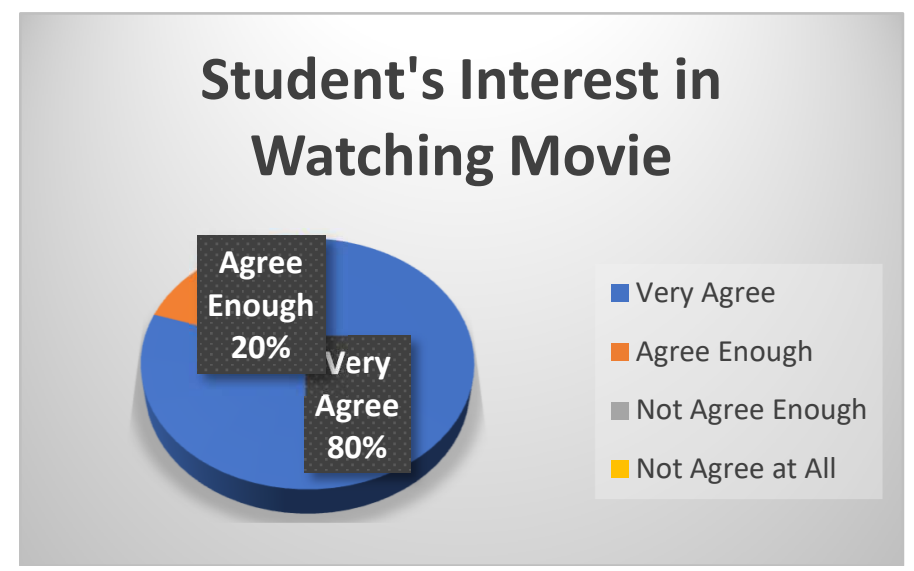

The result showed that $80 \%$ of students of the 4 th semester had a big interest in watching a movie. Another $20 \%$ of students have enough interest in watching films. This result shows that students who are around 18-20 years old and who are millennials have a great tendency to watch films. There is no single student who does not like to watch movies because according to them it is an interesting method in teaching and learning activities.

Fig. 2. Movie-Suitability with the Lesson Subject

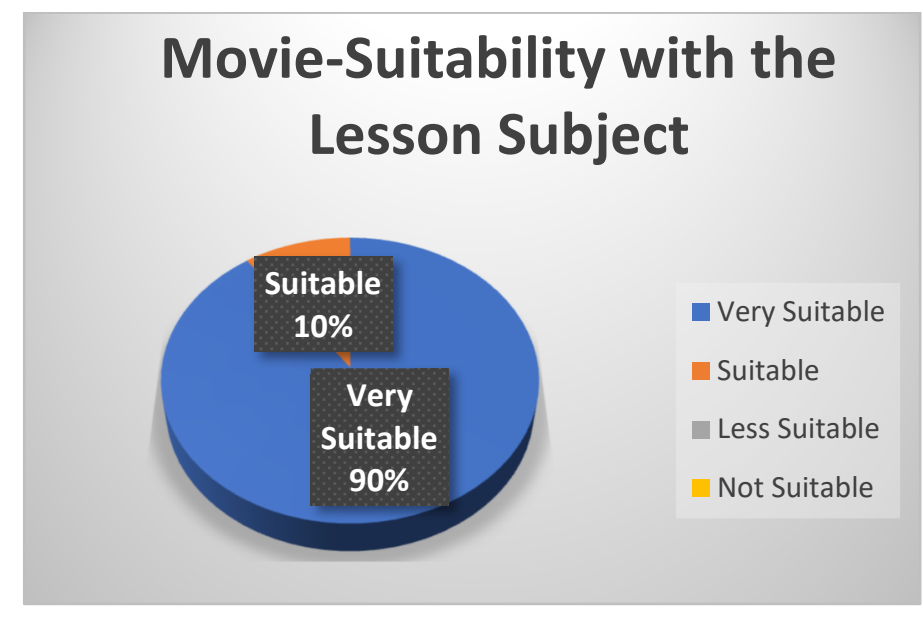

In terms of the suitability of the contents of the film with the lecture material. The total of $90 \%$ students agree that the movie being watched is very suitable for the lesson they have studied before. The rest of $10 \%$ thinks that the film is quite in accordance with the learning material. This question is important because if the film does not have a correlation with the teaching course. It means that this method is not successful and cannot reach the stated learning goals. As the result, the students cannot reach the clear messages in that movie. 
Fig. 3. The Massages in Movie are Understandable

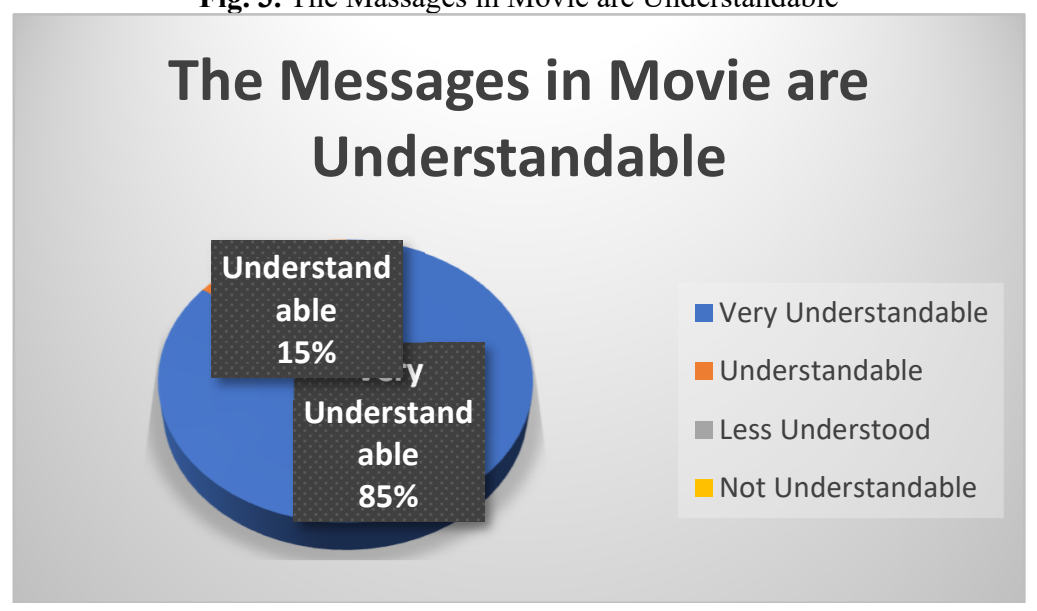

The survey resulted that $85 \%$ students said that the messages in the movie are very understandable for them. Another $15 \%$ of students thought that the message conveyed was understood enough. This is one of the results of the use of audiovisual media in understanding values that are quite heavy to learn and memorize. This understanding is expected to be more easily applied in the daily lives of students. It also makes $80 \%$ students prefer to study with this media.

Fig. 4. I Prefer Studying by Watching Movie

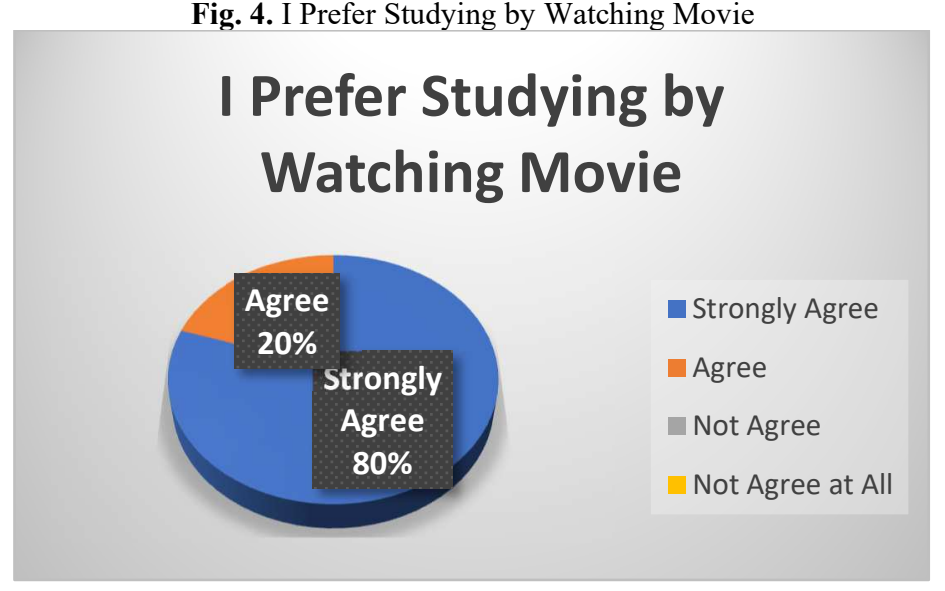

The last point is the suitability of the task given in the form of comments and brief responses to the films. As a result, $95 \%$ of students agree that the assignment given after the lesson is very suitable with their competency. The other $5 \%$ said that the task was in accordance with their competencies. It shows that the majority of students in the class feel happy when studying and working on assignment.

Fig. 5. The Assignment that Given are Suitable 


\section{The Assigment that Given Are Suitable}

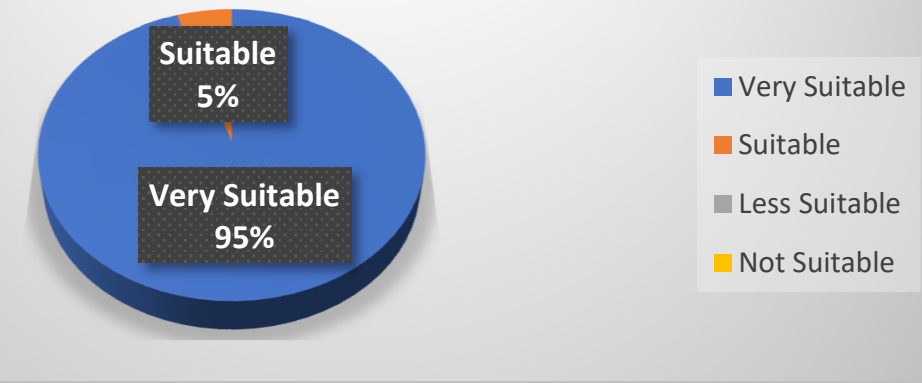

Based on a survey which is held in the form of writing tasks to to all members of the class the result of learning is the following:

Fig. 6. Form of Writing Tasks of All Members

\begin{tabular}{|c|c|c|c|c|c|c|c|c|}
\hline \multicolumn{2}{|c|}{ 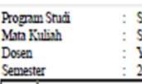 } & 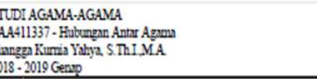 & \multicolumn{3}{|c|}{$\begin{array}{l}\text { KELAS } \\
\text { RYLAH NAFASISWA }\end{array}$} & \multicolumn{3}{|c|}{$\begin{array}{l}C_{3} \\
22 \\
\end{array}$} \\
\hline \multirow[b]{2}{*}{ No } & \multirow[b]{2}{*}{ NMI } & \multirow[b]{2}{*}{ Nama } & \multicolumn{6}{|c|}{ Nilai } \\
\hline & & & $\begin{array}{c}\text { Harian } \\
\% \%\end{array}$ & \begin{tabular}{|c} 
Tugas \\
3096
\end{tabular} & $\begin{array}{l}\text { UTS } \\
2096\end{array}$ & $\begin{array}{l}\text { UAS } \\
509 \%\end{array}$ & Nilai Angka & Nilai Huruf \\
\hline 1. & 3820172130694 & BNTANG RAMADHANI & 89 & 90 & 91 & 92 & 91.20 & $\mathrm{~A}^{+}$ \\
\hline 2. & 3820172130696 & FARUZZ NADA NOVALLANA & 87 & 88 & 91 & 93 & 91.10 & $\mathrm{~A}^{+}$ \\
\hline 3. & 3820172130698 & HIDIA TARAUNI & 88 & 89 & 91 & 93 & 91.40 & $\mathrm{~A}^{+}$ \\
\hline 4. & 3820172130700 & HADA REZZMA $F$ & 89 & 89 & 94 & 95 & 93.00 & $\mathrm{~A}^{+}$ \\
\hline 5. & 3820172130701 & MAE FARUS & 87 & 88 & 91 & 93 & 91.10 & $\mathrm{~A}^{+}$ \\
\hline 6. & 3820172130703 & MANAZIL PUTRIANA & 88 & 89 & 91 & 92 & 90.90 & $\mathrm{~A}^{+}$ \\
\hline 7. & 3820172130705 & MAYA FRDAYYANTI & 88 & 89 & 92 & 94 & 92.10 & $\mathrm{~A}^{+}$ \\
\hline 8. & 3820172130706 & MEYDNA RIZKA ANGGRAINI & 88 & 88 & 91 & 92 & 90.60 & $\mathrm{~A}^{+}$ \\
\hline 9. & 3820172130707 & MUKFIAH FUADAH QOSDM HABIBAH & 86 & 88 & 88 & & 4.00 & D \\
\hline 10. & 3820172130708 & NADIYA AVIVAH & 87 & 89 & 90 & 92 & 90.70 & $\mathrm{~A}^{+}$ \\
\hline 11. & 3820172130709 & NADYA AMALIYAH & 89 & 89 & 92 & 94 & 92.10 & $\mathrm{~A}^{+}$ \\
\hline 12. & 3820172130712 & NENCHY NOVITASARI & 86 & 88 & 91 & 92 & 90.60 & $\mathrm{~A}^{+}$ \\
\hline 13. & 3820172130713 & NINDA ANJANI & 88 & 89 & 93 & 95 & 92.80 & $\mathrm{~A}^{+}$ \\
\hline 14. & 3820172130714 & NUR AFIFAH RA & 87 & 89 & 91 & 93 & 91.40 & $\mathrm{~A}^{+}$ \\
\hline 15. & 3820172130715 & PRIZIIIA ANUGRAHANI SETYAWAN PUTRI & 88 & 89 & 92 & 92 & 91.10 & $\mathrm{~A}^{+}$ \\
\hline 16. & 3820172130716 & RACHMAH NTAN MUSLMMAH & 88 & 88 & 92 & 94 & 91.80 & $\mathrm{~A}^{+}$ \\
\hline 17. & 3820172130718 & SAFTYA FADLULAH & 87 & 89 & 92 & 94 & 92.10 & $\mathrm{~A}^{+}$ \\
\hline 18. & 3820172130719 & SAQEAH IKIIIN NIEMAAH & 89 & 90 & 93 & 96 & 93.60 & $\mathrm{~A}^{+}$ \\
\hline 19. & 3820172130720 & SEFRDA TNIP. & 88 & 89 & 92 & 92 & 91.10 & $\mathrm{~A}^{+}$ \\
\hline 20. & 3820172130721 & SITI MAULIDA NUR AZIZAH & 87 & 89 & 91 & 93 & 91.40 & $\mathrm{~A}^{+}$ \\
\hline 21. & 3820172130722 & THORIQOH MUSTAQIMAH & 87 & 88 & 92 & 93 & 91.30 & $\mathrm{~A}^{+}$ \\
\hline 22. & 3820172130724 & ZAKTYATUN NADHROH & 87 & 89 & 91 & 93 & 91.40 & $\mathrm{~A}^{+}$ \\
\hline
\end{tabular}


The results show that $95 \%$ students is able to take lessons and capable of doing tasks such as writing a response. Assessment results were based on the accuracy of the contents of the response, comment, and analysis on one or both films that are medium of learning in the classroom.

\section{Why Movie-review?}

This research found that most of students agree in using movie-review methods in teaching the subject 'Interfaith Relations'. The millennial generation is more dominant on visual things. Therefore, the development of teaching methods required teachers to avoid the boredom of the students in following the. It is also easier to understand the messages conveyed through films as a form of implementation of the theories they have previously learned [3].

This is in accordance with Berk's opinion [7] that use of film and video media in learning provides a significant psychological impact on the students. As they watch the movie, voice and picture messages are delivered with transfer of feelings and emotions like sad, angry, happy, and much more. Therefore, their emotions are still in themselves whenever they watch movies that set them in a deep impression.

Like reading, watching movies is an activity capturing the message. The difference is a fact that reading needs more exercise and a high focus, while watching takes little focus and do not need to exercise. Therefore, a child will more quickly recognize how to watch the movie before learning to read words [8].

Reading involves a lot of cognitive works of the students. In reading, students are required to undergo the process of seeing, recognizing letters, paying attention, understanding the meaning, absorbing and processing the obtained meaning, and saving it. At a later, when it is required, they are also required to use the memory back or memorizing [9]. Thus, reading becomes one of the activities that can have a significant impact on the development of student's knowledge, rationally and empirically.

Although watching involves only less effort and does not need a lot of practice, it does not mean watching does not involve skill resulting from the process of reading. According to Berk [7], there are at least 20 potentials generated when the students learn to use the medium of film, such as easily gaining the students' attention, indirectly requiring students to focus, giving students an opportunity to use their imagination, improving student's memory, facilitating the absorption of delivered message, and making learning process more fun and not boring.

The results [10] about the advantages and disadvantages of using the film as a medium of teaching a history shows that most students are interested to learn using the medium of film. They argue that by watching the film, they were able to escape from the medium of monotonous learning of the situation. Class also became interesting and varied so as to help students gain an understanding, stimulate their imagination, concreting things that are abstract, and in the end, able to provide a better learning outcomes.

Watching movies is based on learning experience, affective and cognitive simultaneously. Affective are skills related to the values and taste, while cognitive relates to how the brain works or mental [11]. Studying the theory and abstract concepts will be easier by using audio and visual media than using the text media [12].

In teaching-learning process, improving the cognitive abilities in learning is one of the factors that support success of learners. Cognitive abilities in self-learners can be stimulated through five stages: a) choosing the suitable words in the process of formation of verbal memory; b) selecting the suitable images in formation process of visual memory; c) set the suitable words in the verbal process; d) set the suitable images in the visual models process; e) the integration between verbal and visual representations as a form of units of knowledge [13]. 
In cognitive psychology, knowledge is divided into four categories. The four categories are factual knowledge, conceptual knowledge, procedural knowledge, and metacognitive knowledge. The first knowledge is closely related to knowledge of terminology, details, and the specific elements such as vocabulary, music notes, and natural resources. Conceptual knowledge is closely related to the process of classification, categorization, knowledge of general and specific and relevant knowledge of theories, models, and structures [14].

Third knowledge is knowledge about how to do something. This knowledge is closely related to color mixing skill, a technique in using the algorithm, the implementation of the laws of physics, and the use of scientific techniques. The fourth knowledge is a comprehensive cognitive science and has become the consciousness within oneself. This knowledge is closely related to knowledge about strategic knowledge, cognitive tasks, and knowledge of oneself (self-knowledge) [14].

In metacognitive knowledge, a person is able to identify an issue, analyze it, and then provide a solution to the problem. Differences in problems and background of problems require different emphasis and solutions from one another. Metacognitive intelligence will appear in such matters. Therefore, it is not wrong if the intelligence or knowledge is considered to be a combination of knowledge of the situation, condition, and cultural knowledge [14].

The learning process of subjects 'Interreligious Relations' with movie as a medium is an acquisition of metacognitive knowledge. The presentation of information and knowledge through audio and visual indirectly indicates a combination of affective and cognitive side. It helps planting simultaneously two inner bits of intelligence of students, i.e. the intellectual and emotional intelligence.

To achieve the targeted level of cognitive, cognitive learning process has 6 categories. The first category is the remember. Evaluation form in this category is recognizing and recalling. The second category is understanding. Evaluation forms that describe the understanding is interpreting, exemplifying, classifiying, summarizing, inferring, comparing, and explaining.

The third category is further limited understanding of the above categories, which correspond to the level of student learning. The third category is applying, which includes the process of executing and implementing. The fourth category is analyzing which includes differentiating, organizing, and attributing. The fifth category is evaluating in which students are required to check the validity versatile (checking) and judges (judging). The last category is creating which requires students to generating, planning, and producing [14]. Even so, it is inappropriate to compare one category to another category, because each category has a characteristic each corresponding to a particular subject.

With the prism of these categories, the learning process in subject "Interfaith Relations" can be considered effective. In using film medium, the students indirectly used six cognitive processes to achieve the expected levels. In the category of remembering, students are required to recognize (recognizing) the forms of tolerant and intolerant acts in inter-religious relations. In the category of understanding, students were asked to describe and interpret what they have seen and they have found in the film. Then, they were asked to resume in a short response (summarizing).

In the category of applying, students are trained for executing / carrying out theories that have been studied previously in a real form of film. In the next category, analyzing, students are required to be able to attract coherence between the film's story and the reality, especially in inter-religious relations. Henceforth, they are asked to bring criticism (critiquing) about a discrepancy between film and actual facts or just the opposite, criticized the implementation (das Sein) that does not fit as they should happen (das sollen). 
In the latter category, the learning process can also be entered into the stage of creating. Students are required to create a social awareness on how to resolve the problems of communication in the relationship among religious communities. As stated in response to one of the students, they felt that good things about harmony and peace that appear in the two films are realized in the real world. Creation of social awareness within the student is an important step in order to create a generation with sensitiveness to their surrounding community.

\section{Reality Construction of Inter-Religious Harmony}

However, using film as learning media also needs special attention from teachers. Film is also a popular culture that has two functions, as the construction of reality and representation of socio-cultural reality. The first function is to expose a wide range of realities in order to leading opinion of audience in accordance with filmmakers' (producer, screenwriter, and director) direction and desire. Therefore, it is often considered as a 'side effect' of the messages conveyed through digital media such as movies, since it only highlights something which 'is considered' important for author [5].

Movies are also able to create a different fact construction to reality (Kenny, 2001: 14). The things that are considered to be true can appear as a false entity in a film. Conversely, any wrong entity can be represented as one thing good and praiseworthy. In war-themed films, for example, some films that tells the World War or the Cold War have differences between scripts and characters. In the "movie A", someone is seen as the protagonist, and in other films, he could be incarnated as antagonists.

The second function is the representation of social reality. Some issues and anxieties cannot be always expressed directly because of some interests and considerations. A strategy of representation in media to convey the messages is through film. According to Arnold (2008), the relationship between film as a medium for representation and reality behind its representation is a two-way relationship. In one side, film or television is a real picture of social, cultural, and political reality, and on the other hand, events in real life is affected by vision and story behind the film [6].

Because of these two things, the teachers need to be more selective in choosing movies become a medium of learning. Because form of fiction, the film is capable of carrying audience's opinions and emotions. It is a real illustration of abstract concepts and theories [16] which bring a feeling into audience's imagination [10]. Teachers need to avoid films and impressions that did not comply with the direction of learning, or worse, imparts negative messages, stereotyping, labeling, and bad stigma against peopla.

In addition to adjusting film content with the content of lessons, teachers also need to be selective about the category of film to be used [7]. Some films tried to convey a good message, but its package can only be digested by an adult audience. Starting from the look, fashion, language structures, style of speech, to the various behaviors (that) 'is considered' reasonable by adults may not be suitable for teenagers, especially to a medium of learning.

The film used in the subject 'Interreligious Relations' is a fiction which is not based on a true story. This is different from a documentary film which is a representation of a story that really happened. However, construction of reality through the two films is also required in order to construct memory of peace and instill message of peace between religions. The process of inter-religious communication in order to achieve peace needs a recall for the good moments (co-existence) of the various parties. When a good memory does not exist, it takes an effort to construct a memory of reality in order to create peace among different parties. It means that such construction can build a memory on peace, co-existence, and harmony in the level of symbolic dimension in life [17], [18]. 
By the same reason, media became learning tools for teachers. With regard to a fact that entire student learners are Muslims and live in an Islamic Boarding Schools environment, it is confirmed that these students are accustomed to living in a homogeneous atmosphere. Background and tribal homelands of diverse students also cannot be confirmed that each of them has a memory of peace, or (at least) an experience of meeting with people of other faiths.

As already mentioned, the planting of peace memory is one important thing in creating a harmonious and peaceful society. In this learning process, students were asked to implement the phenomenological view in the process of knowing nature, attitude, and behavior of followers of other religions and beliefs. The phenomenological view requires two main concepts, namely epoche and eidetic vision [19].

The phenomenological view is needed in order to create a strong kindship between people of different religions. As illustrated in Hasan al-Banna's Role of the Brotherhood, a fraternity must start from at-ta'aruf (knowing each other), at-tafahum (understanding each other), and comes down to at-ta'awun (helping each other) [19]. Therefore, epoche-based attitude is needed before starting to learn this subject. If not, the student will only stick to memorizing and stereotyping against the other party before starting to approach with each other.

By coincidence, a movie Aisyah, Biarkan Kami Bersaudara, shows that at the beginning the native residents feel fear because they never met directly with Muslims. They just hear how the abomination of Muslims in communal conflict happened in Ambon. This stereotype is gradually reduced by an effort to know each other between teacher Aisyah and local residents. After they reached a point of understanding, the residents understand the obligation of teacher Aisyah as Muslim like ablution, prayer, fasting, and not consume pork. Teacher Aisyah also understands that the native residents fear presence of a Muslim in their village.

In the last stage, teacher Aisyah and people around seemed to help each other. Teacher Aisyah helps residents in the provision of clean water, helps children in the preparation of Christmas celebration, and helps her students who are in family problem. Residents also help teacher Aisyah to return in Eid day by giving some moneys to buy a ticket and provide food for sahur and iftar. This message is expected to be received by the students, and they can practice it in the domain of inter-religious relations.

Through both of these films, teachers encourage students to create a wonderful memory of a peace. Peace or tolerance are not static spectrum [17]. The relationship among religious communities in the region is seemingly tolerant, but at any other times in a state of intolerance. Good communication (Yahya, 2018a: 240) and meeting space (melting pot) in the real world and the virtual world are efforts in creating a tolerant state among them (Ahnaf, Takwin, Mudzakkir, Salim, \& Hamdi, 2016: 164).

A similar effort is ever undertaken Sheetal V. Desai [21] in implementing the cross-cultural introduction in class through the medium of film. Desai and his partners did the learning and the introduction of a different culture by using 101 movies. Each film was analyzed with methods of analysis of one movie, the comparison between the two films, and a comparison among several films. In conclusion, they argued that the film is an incredible and amazing medium of learning. It was able to bring the nuance and cultural theories in the classroom (Desai et al., 2018: 413).

The use of film as a medium in spreading positive values has also been carried out by Chuchai Smithikrai [12]. He researched 11 films that bring positive messages. At the beginning of the semester, each respondent was given a few questions regarding their motivation for applying positive character and behavior of their daily life. At the end of the second semester, after they made several activities to watch these films and accompanied by group discussion, 
they are asked by similar question. The result showed that there were significant changes in understanding and motivation of the students in demonstrating positive traits and behaviors.

The results of these studies constitute what this study has achieved with similar method of film. Positive values, such as harmony, forgiveness, tolerance, mutual respect, honesty, and courage become key words in the subject of "Interfaith Relations". Those values have long been understood by the students. However, its implementation in inter-religious life is still complex and difficult to understand.

Through both of these films, positive values above can be taught in easy and fun, but long lasting ways for the students. When they are given a task in form of brief comments in oral tests and a short response in writing tests, positive values emerge in their responses. Without having to use memorization, students can express their positive perspectives to the film, and it became an ultimate goal of this subject.

\section{Conclusion}

The rapid advancement of information technology development in this era provides new challenges and opportunities for teachers. Teaching methods need further development in order to make sure that student can concentrate and enjoy learning process and has an ability to capturing messages. Using the film as a medium of learning is a way of these developments.

In addition to be fun, learning with movie-review method also has many advantages over traditional reading. The combination between affective and cognitive intelligences in using this method is able to assist students in developing knowledge and getting emotional messages. This makes the students get intellectual and emotional experience in watching movies.

In the course of "Interreligious Relations" in Department of Comparative Study of Religions, Faculty of Ushuluddin, University of Darussalam Gontor, lecturer used moviereview as a learning medium. In addition to the need to construct a reality and create a good memory of coexistence in society, students who live in a homogeneous atmosphere in schools need to learn to get acquainted with the realities that exist in heterogeneous and pluralistic society. Therefore, movie-review is required in order to instill social awareness about relationship between religion and as one of the attempts epoche to different beliefs and religions.

As a result, students in addition to enjoying the learning process, they are also capable of capturing messages quickly and easily. They are easier to understand the implementation of the theories in 'Interreligious Relations' which was previously taught. In addition, visualization of good scenes is possible to transmit positive values of tolerance, harmony, tolerance, honesty, and openness in the film into emotional and cognitive skills of students. It will be a beginning phase to further know each other and form a bond together in accordance with al-Banna's Role of Brotherhood.

\section{References}

[1] Y. K. Yahya, "Posisi Muslim Dalam Menentukan Pilihan di Pilpres 2019," POLITEA J. Pemikir. Polit. Islam, vol. 2, no. 1, pp. 55-70, 2019.

[2] Y. K. Yahya, "Pengaruh Penyebaran Islam di Timur Tengah dan Afrika Utara: Studi Geobudaya dan Geopolitik," Al-Tsaqafa J. Perad. Islam, vol. 16, no. 1, pp. 44-62, 2019.

[3] R. Wahyuningsih, "Using Film Reviews to Improve Students' Attitudes on Vocabulary and Writing Skill in General English Classes at the Faculty of Liberal 
Arts, Universitas Pelita Harapan, Tangerang, Indonesia," in Konferensi Linguistik Tahunan Atma Jaya 17, 2019, no. 17, pp. 265-269.

[4] C. H. D. Surwati, "Konstruksi Feminisme dalam Film Indonesia ( Analisis Wacana Kritis Konstruksi Feminisme dalam Film Indonesia Karya Sutradara Nia Dinata ), J. Komun. Massa, vol. 1, no. 1, pp. 1-24, 2012.

[5] D. Nayyar, Modern Mass Communication. 2007.

[6] G. B. Arnold, Conspiracy Theory in Film, Television, and Politics. London: Praeger Publishers, 2008.

[7] R. Berk, "Multimedia teaching with video clips: TV, movies, YouTube, and mtvU in the college classroom.," Int. J. Technol. Teach. Learn., vol. 5, no. 1, 2009.

[8] S. Goodman, Teaching Youth Media: A Critical Guide to Literacy, Video Production, and Social Change. New York: Teachers College Press, 2003.

[9] S. Ampuni, "Proses Kognitif Dalam Pemahaman Bacaan," Bul. Psikol. Univ. Gadjah Mada. Fak. Psikol., vol. 6, no. 2, pp. 16-26, 1998.

[10] R. Husmiati, "Kelebihan Dan Kelemahan Media Film Sebagai Media Pembelajaran Sejarah,” J. Sej. Lontar, vol. 7, no. 2, p. 61, 2010.

[11] T. Haryadi and A. Aripin, "Melatih Kecerdasan Kognitif, Afektif, dan Psikomotorik Anak Sekolah Dasar Melalui Perancangan Game Simulasi 'Warungku,", ANDHARUPA J. Desain Komun. Vis. Multimed., vol. 1, no. 2, pp. 122-133, 2015.

[12] C. Smithikrai, "Effectiveness of Teaching with Movies to Promote Positive Characteristics and Behaviors," Procedia - Soc. Behav. Sci., vol. 217, pp. 522-530, 2016.

[13] R. E. Mayer, Multimedia Learning, Second., no. 2. New York: Cambridge University Press, 2009.

[14] L. W. Anderson and D. R. Krathwohl, A taxonomy for learning teaching and assessing: a revision of Bloom 's taxonomy of educational objetives. New York: Addison Wesley Longman, 2001.

[15] R. Kenny, Teaching TV Production in a Digital World. Colorado: Libraries Unlimited, 2001.

[16] W. J. Casper, J. E. Champoux, J. D. Watt, P. D. Bachiochi, D. J. Schleicher, and C. Bordeaux, "Feature film as a resource in teaching I-O psychology," Ind. Psychol., vol. 41, no. 1, pp. 83-95, 2003.

[17] Y. K. Yahya, "Toleransi Antar Agama Dan Antar Etnis Di Desa Mamahak Teboq Kalimantan Timur,” Palita J. Soc. Res., vol. 3, no. 2, pp. 165-180, 2018.

[18] S. Campbell, "What is Successful Peacebuilding?," Cathol. Reli. Serv., 2007.

[19] Y. K. Yahya, "PHENOMENOLOGICAL APPROACH IN INTERFAITH COMMUNICATION: A Solution to Allegation of Religious Blasphemy in Indonesia," Al-Tahrir J. Pemikir. Islam, vol. 18, no. 2, pp. 237-254, 2018.

[20] M. I. Ahnaf, B. Takwin, A. Mudzakkir, H. Salim, and A. Z. Hamdi, Studi Tentang Toleransi dan Radikalisme di Indonesia: Pembelajaran dari 4 Daerah Tasikmalaya, Jogjakarta, Bojonegoro, dan Kupang. Jakarta: INFID, 2016.

[21] S. V. Desai, S. S. Jabeen, W. K. Abdul, and S. A. Rao, "Teaching cross-cultural management: A flipped classroom approach using films," Int. J. Manag. Educ., vol. 16, no. 3, pp. 405-431, 2018. 